\title{
A RANDOMIZED CLINICAL TRIAL OF ORAL STEROIDS FOR ULNAR NEUROPATHY IN TYPE 1 AND TYPE 2 LEPROSY REACTIONS
}

\author{
José Antonio Garbino', Marcos da Cunha Lopes Virmond², \\ Somei Ura', Manoel Henrique Salgado², Bernard Naafs ${ }^{3}$
}

\begin{abstract}
Background: Steroids regimens in leprosy neuropathies are still controversial in botth types of reactions. Method: For this trial, 21 patients with ulnar neuropathy were selected from 163 leprosy patients, 12 with type 1 reaction (TIR) and nine with type 2 (T2R). One experimental group started with prednisone 2 $\mathrm{mg} / \mathrm{kg} /$ day and the control group with $1 \mathrm{mg} / \mathrm{kg} /$ day. A clinical score based on tests for spontaneous pain, nerve palpation, sensory and muscle function was used. Neurophysiological evaluation consisted on the motor nerve conduction of the ulnar nerve in three segments. Student " $t$ " test for statistical analysis was applied on the results: before treatment, first week, first month and sixth month, between each regimen and types of reaction. Conclusion: In both reactions during the first month higher doses of steroids produced better results but, earlier treatment with lower dose was as effective. Short periods of steroid, $1 \mathrm{mg} / \mathrm{Kg} /$ day at the beginning and,tapering to $0,5 \mathrm{mg} / \mathrm{Kg} /$ day or less in one month turned out to be efficient in $\mathrm{T} 2 \mathrm{R}$.
\end{abstract}

KEY WORDS: leprosy, ulnar neuropathy, steroids, neurophysiology.

\begin{abstract}
Ensaio clínico sobre o tratamento com esteróides via oral da neuropatia ulnar em reação tipo 1 e tipo 2 da hanseníase

Resumo - Introdução: O tratamento da neuropatia da hanseníase com esteróides é ainda controverso nos dois tipos de reações. Método: Neste ensaio, de 163 pacientes foram selecionados 21 com neuropatia ulnar, 12 com reação tipo 1 e 9 com tipo 2. Um grupo experimental iniciou com 2 mg/kg/dia e o grupo controle com $1 \mathrm{mg} /$ $\mathrm{kg} /$ dia. Foi composto um escore clínico pela avaliação da sensação dolorosa espontânea, palpação de nervos e funções sensitiva e motora. Realizou-se a condução nervosa motora do nervo ulnar em três segmentos. Aplicaram-se os estudos estatísticos com o teste t de Student nos resultados: antes do tratamento, primeira semana, primeiro mês e sexto mês. Conclusão: Em ambas as reações dosagens mais elevadas iniciais produziram melhores resultados, mas a dose menor quando administrada precocemente foi igualmente efetiva. Períodos curtos com doses efetivas, $1 \mathrm{mg} / \mathrm{Kg} /$ dia no início e reduzindo-se para 0,5 mg/Kg/dia ou menos em um mês foram eficientes na reação tipo 2 .
\end{abstract}

PALAVRAS-CHAVE: hanseníase, neuropatia ulnar, esteróides, neurofisiologia.

Immune response to Mycobacterium leprae may lead to disability due to nerve damage, which occurs mostly during the acute inflammatory episodes named reactions. According to the immunity, leprosy patients can develop distinct clinical groups': polar tuberculoid tuberculoid (TT), borderline tuberculoid (BT), borderline borderline (BB), borderline lepromatous (BL) and polar lepromatous (LL). Mainly two types of reactions are known, the type1 leprosy reactions (T1R) or reversal response, which happens in groups that have cell-mediated immune reaction,
$\mathrm{TT}, \mathrm{BT}, \mathrm{BB}$ even in BL patients and, the type 2 leprosy reaction (T2R) or erythema nodosum leprosum, which is predominantly immune-complex mediated and occurs only in BL and LL. Treatment of these reactions in nerves usually requires immunosuppressive or immunomodulating drugs. Therefore it is relevant to study different regimens in the treatment of these episodes in order to define the most appropriate ones. Oral prednisone or prednisolone are the most often used drugs. Dosages vary from 30-40 $\mathrm{mg} /$ day $^{2-4}$ to $60-80 \mathrm{mg} /$ day in severe cases $^{5-8}$. Based on

\footnotetext{
'Instituto Lauro de Souza Lima, Bauru SP, Brasil; ${ }^{2}$ Departamento de Produção da Faculdade de Engenharia de Bauru, Universidade do Estado de São Paulo, Bauru SP, Brasil; ; ${ }^{3}$ epartamento de Dermatologia do Centro Médico da Universidade de Leiden, Holanda.
}

Received 2 June 2008, received in final form 17 September 2008. Accepted 3 October 2008.

Dr. José Antônio Garbino - Instituto Lauro de Lima - Caixa Postal: 3021 - 17034-971 Bauru SP - Brasil. E-mail: garbino.blv@terra.com.br 
a few studies the standard starting dose of prednisone/ prednisolone for field use was established to be approximately $40 \mathrm{mg} / \mathrm{day}^{9,10}$. However, there are no references available relating body weight to steroid doses.

The follow-up of motor nerve function using Voluntary Muscle Testing (VMT) gives insight into behavior of nerves during reactions and treatment ${ }^{11}$. Magora ${ }^{12}$ suggested using motor nerve conduction (MNC) for nerve monitoring in leprosy neuropathy. Naafs and Dagne ${ }^{13}$ and later Naafs and

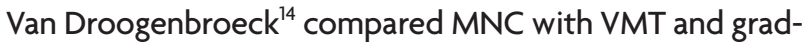
ed sensory testing (GST). The last two authors gathered all the parameters to compose a nerve severity index.

In this study, measurement of the MNC along the ulnar nerve was selected to investigate differences in nerve responses in the two types of leprosy reactions, type 1 and type 2, under two different steroid regimens advised by the Brazilian guidelines for leprosy control ${ }^{15}$, initial doses of $1 \mathrm{mg} / \mathrm{kg} /$ day to $2 \mathrm{mg} / \mathrm{kg} /$ day.

\section{METHOD}

Patients presenting leprosy reaction and with active ulnar nerve involvement were selected at the outpatient department of the Instituto Lauro de Souza Lima in Bauru, Brazil. All patients provided informed written consent and the study was approved by the institutional Ethical Committee. Patients at risk of a neuropathy other than leprosy neuropathy were excluded, i.e. diabetes, alcoholism, HIV infection, also with family history of hereditary neuropathy and over 60 years of age. Patients with inactive neuropathy and/or chronic neuropathic pain, with nerve abscess and with nerves that had been submitted to neurolysis, as well as patients with a contraindication for steroids were also excluded.

Reactions were defined as:

Type 1 reaction (TIR) in the $T T, B T, B B$ and BL patients: an increased inflammation of existing lesions with or without nontender new lesions and/or acro-edema. Nerves may be enlarged, tender and show loss of function.

Type 2 reaction (T2R) in the LL patients: a sudden appearance of inflamed papules, nodules and plaques that are tender on palpation. The patient may be ill and run a mild fever. There may be signs of involvement of other organs, e.g., eyes, testes, joints, lymph glands and periosteum. Nerves may be enlarged, tender and show loss of function.

Out of 163 leprosy patients examined during the period of September 2003 to August 2005, 21 patients were eligible, and included in the study: 17 men and 4 women (ages 21-60, mean: 41.5). Twelve patients had TIR ( 3 BT and $9 \mathrm{BB}$ ) and nine T2R, all were $\mathrm{LL}$.

Patients of both reaction types were assigned to treatment groups: experimental or control. The patients were assessed immediately prior to the beginning of treatment $\left(1^{\text {st }}\right)$, after one week $\left(2^{\text {nd }}\right)$, after one month $\left(3^{\text {rd }}\right)$ and thereafter monthly, the last follow-up occurred after six-months ( $8^{\text {th }}$ assessment). All patients were submitted to clinical and dermatological exami- nation in order to classify the leprosy groups, a general clinical evaluation and laboratory tests were performed to assess blood cells, blood sugar levels, liver and kidney functions.

\section{Clinical evaluation}

1. Assessment of spontaneous pain - this utilizes a visual analog scale (VAS), in which zero represents no pain and 10 represents unbearable, incapacitating pain ${ }^{16}$. 2. Nerve palpation (NP) - this is done at the elbow. Size and tenderness were evaluated and graded: 0 (normal palpation) -5 (maximum nerve enlargement $)^{17}$. 3. Graded sensory testing (GST) - nylon monofilaments (SORRI - Bauru/ Brazil Kit ${ }^{18}$, 0.5, 1, 2, 4, 10, $100 \mathrm{~g}$ ), were used in two areas innervated by the ulnar nerve, one in the hypothenar region and one in the little finger. The results were computed to a maximum of 12 points, when no filament was felt in a completely damaged nerve, and zero when all filaments were felt for a normal nerve. 4. Voluntary muscle testing (VMT) - The tested muscles were the abductor digiti minimi muscle and the first dorsal interosseus. A normal score would be 10 points $(2 \times$ 5) and when paralyzed, 0 points. In this study it was employed a reverse scale in order to align the results and build the score. These results were comparable with the other tests, in which the greater values relate to diminishing function. A final clinical score (CS) was calculated by the somatory of the results of VAS, NP, GST and VMT. The VAS and NP were applied only by one examiner and the GST and VMT were applied by the institution staff of therapists.

\section{Neurophysiologic evaluation}

Motor nerve conduction (MNC) studies were carried out over three segments of the ulnar nerve. Recording of the compound motor action potential (CMAP) was done with the active recording electrode on the abductor digiti minimi muscle belly and the reference electrode on a tendon or a bony surface ${ }^{19}$. The CMAP amplitude by supramaximal stimulation, measured from the base line to the negative spike, is a function of the number of functioning motor axons ${ }^{19}$.

1. The distal latency was measured over an $8 \mathrm{~cm}$ long segment from the active recording electrode to the wrist; the recording electrode was attached on the muscle belly. 2 . The nerve was also stimulated just below the elbow and $11 \mathrm{~cm}$ proximal. The conduction velocity over the forearm segment and across the elbow was computed. 3. The CMAP temporal dispersion (TD), i.e., the duration of $\mathrm{CMAP}^{19}$, was measured below and above the elbow. Its values, in percentage, were summated. 4 . The minimum value of the $F$ wave latency, related to demyelination in all segments of the nerve from stimulating electrode to spine and back to the recording electrode, was measured over a series of 20 stimuli.

The period between the start of symptoms and the beginning of treatment was recorded as less than three months $(<3 \mathrm{~m})$ or more than three months but less than six ( $>3<6 \mathrm{~m}$ ).

Patients with T1R and T2R were randomly selected and two random sequences were built, by throwing a coin, for either ex- 


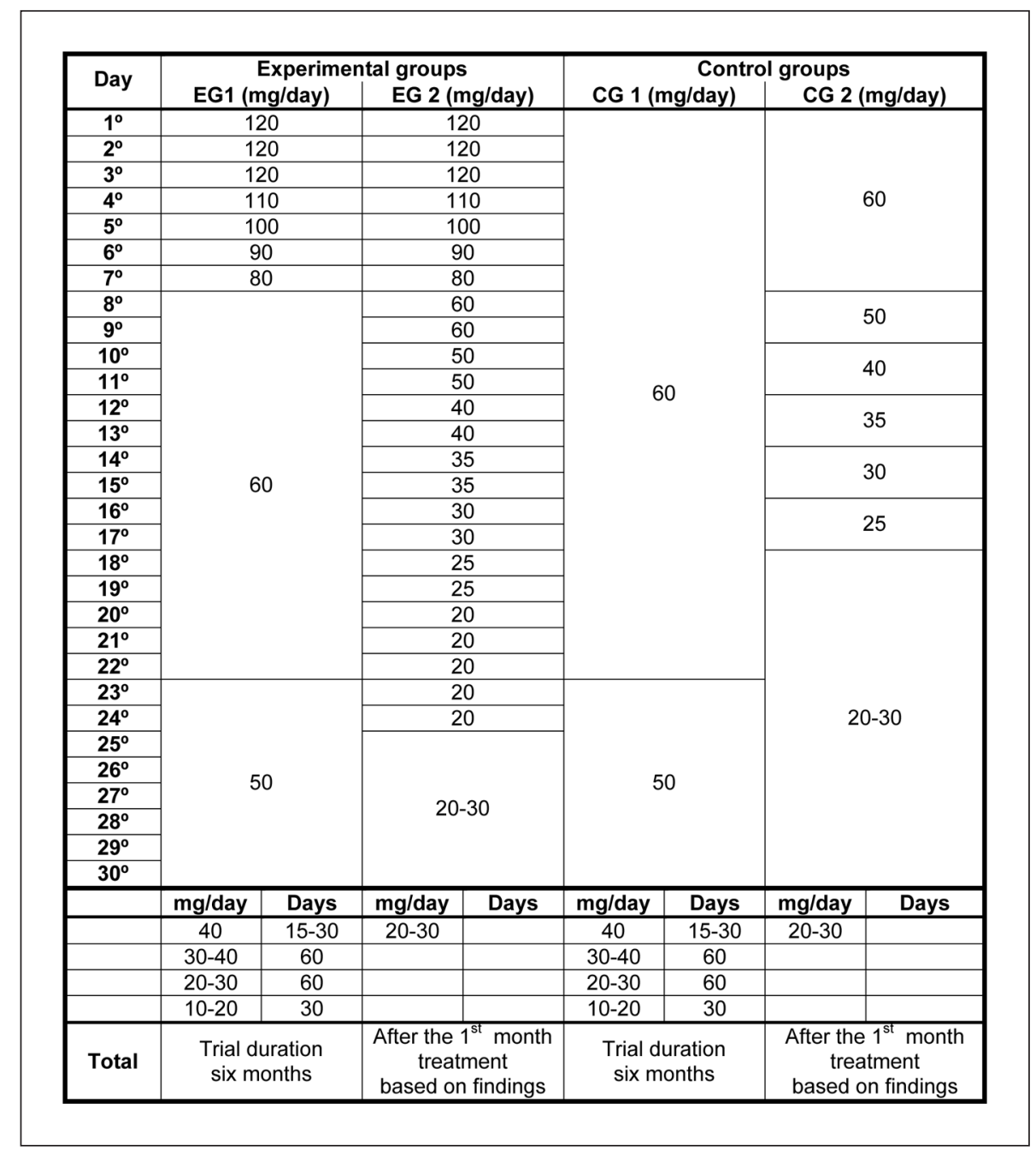

Fig 1. Treatment regimes of experimental groups in $T 7 R$ and $T 2 R$ and control groups (1 and 2) in $T 7 R$ and $T 2 R$, considering a patient with a $60 \mathrm{~kg}$ bodyweight.

Table 1. Distribution of nerves with active neural involvement, as type of reaction, grade of severity and duration of symptoms.

\begin{tabular}{lccccccc}
\hline Grade & \multicolumn{2}{c}{ T1R (time) } & & \multicolumn{2}{c}{ T2 R (time) } & \multirow{2}{*}{ Total of nerves } \\
\cline { 2 - 3 } \cline { 5 - 6 } & $<3 \mathrm{~m}$ & $>3<6 \mathrm{~m}$ & & $<3 \mathrm{~m}$ & $>3<6 \mathrm{~m}$ & \\
\hline Partial lesion & 12 & 5 & & 8 & 3 & 28 \\
Complete paralysis & 0 & 2 & & 1 & $3 *$ & 6 \\
Total of nerves & 12 & 7 & & 9 & 6 & 34 \\
\hline
\end{tabular}

*These nerves have presented the symptoms for more than six months.

perimental group (EG), one receiving prednisone $2 \mathrm{mg} / \mathrm{kg}$ (12 patients), or other control group (CG), which received $1 \mathrm{mg} / \mathrm{kg}$ (nine patients), as initial treatment. This resulted in four groups: EG T1R, CG T1R and EG T2R, CG T2R (Fig 1).

Results of the CS and the neurophysiologic parameters at the beginning of the study ( $1^{\text {st }}$ assessment) were compared with the results obtained after the first week ( $2^{\text {nd }}$ assessment), with the results after the first month ( $3^{\text {rd }}$ assessment) and following the $6^{\text {th }}$ month ( $8^{\text {th }}$ assessment), of each reaction type in the ex- perimental and control groups, using the Student " $t$ " test for statistical analysis.

\section{RESULTS}

Out of 21 patients, 15 (71.4\%) had finished multidrugtherapy around 17.7 months before the symptoms started. Eleven patients were taking inappropriate prednisone doses (mean $0.17 \mathrm{mg} / \mathrm{kg} /$ day) prior to inclusion in the protocol. The responses of their nerves were compared 


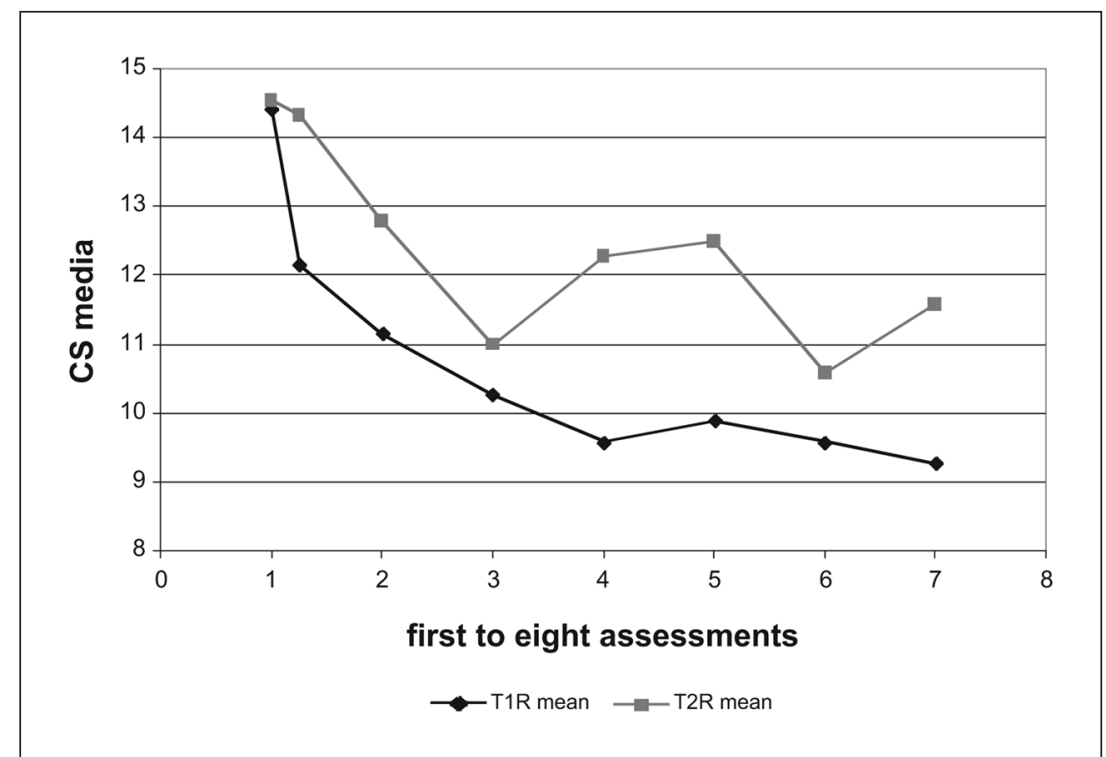

Fig 2. Mean of CS nerves results in patients with T1R and T2R (EG and CG together). The first CS mean was prior to the treatment, the second was after at the end of the first week, the third at the end of the first month and thereafter monthly until the last occurence at the end of the sixth month.

Table 2. The neurophysiological results in patients of experimental group (EG) and control group (CG) (TTR and T2R) comparing the $7^{\text {st }}$ evaluation with the $2^{\text {nd }}$, the $7^{\text {st }}$ evaluation with the $3^{\text {rd }}$ and $7^{\text {st }}$ evaluation with the $8^{\text {th }}(n=28)$. The highlighted data are the results with statistical significance and the underlined data are the borderline results.

\begin{tabular}{lccc}
\hline Steroid regimens EG $\times$ CG & $1^{\text {st }} \times 2^{\text {nd }}$ & $1^{\text {st }} \times 3^{\text {rd }}$ & $1^{\text {st }} \times 8^{\text {th }}$ \\
\hline Distal latency & 0.057 & 0.082 & 0.095 \\
CMAP wrist & 0.968 & 0.380 & 0.663 \\
CV in the forearm & 0.023 & 0.057 & 0.787 \\
CMAP at the elbow & 0.981 & 0.279 & 0.310 \\
CV across elbow & 0.116 & 0.299 & 0.167 \\
CMAP above elbow & 0.322 & 0.680 & 0.267 \\
TD (elbow + above) & 0.095 & 0.032 & 0.703 \\
F wave & 0.054 & 0.157 & 0.121 \\
\hline
\end{tabular}

with the results obtained in the patients without previous treatment. No significant differences were found. They were therefore included in the overall assessment.

Forty-two ulnar nerves from 21 patients were studied. Eight nerves did not show any active neural involvement during the study, six nerves were completely damaged, and 28 nerves were followed by CS and neurophysiology. The distribution of nerves according to type of reaction, and duration of symptoms are demonstrated in Table 1.

During the study, six out of the nine T2R patients needed additional drug treatment 2-3 months after initiation of treatment with prednisone. They received tha- lidomide as an immunomodulator in doses of 100-200 $\mathrm{mg} /$ daily and a temporary slight increment of steroids. None of the TIR patients needed additional treatment. At the end of the time frame to develop this protocol all TIR patients were still on steroids, but tapering off, as well as six (out of 9) of the T2R group.

The values found for the CS within the four groups, when compared within each pair (before treatment, after one week, after 1 and 6 months), showed no significant differences, either for the EG compared with the CG (including both TIR and T2R) or for the TTR group compared with the T2R group (including both EG and CG). However, when the results before treatment ( $1^{\text {st }}$ evaluation) and after 6 months ( $8^{\text {th }}$ evaluation), were compared for each group, all groups showed significant improvement during the trial period (Student $t$ test, $\mathrm{p}=0.000$ for T1R and $\mathrm{p}=0.046$ for T2R).

The graphic representation of the mean CS values (Fig 2) shows an obvious visual difference favouring TIR cases and a clear tendency to deterioration within the $T 2 R$ group during dose reduction.

\section{Neurophysiologic data}

The most frequent abnormal findings observed were in the $\mathrm{CV}$ across the elbow (83.33\%), $\mathrm{F}$ wave latency $(69.44 \%)$ and in the TD at the elbow and above (across the elbow) (52.77\%), followed by the CV along the forearm (38.89\%) and the distal latency (30.56\%).

The statistical differences between the parameters obtained in the EG and the CG are compared in Table 2, including all patients, independent on the type of reaction. 


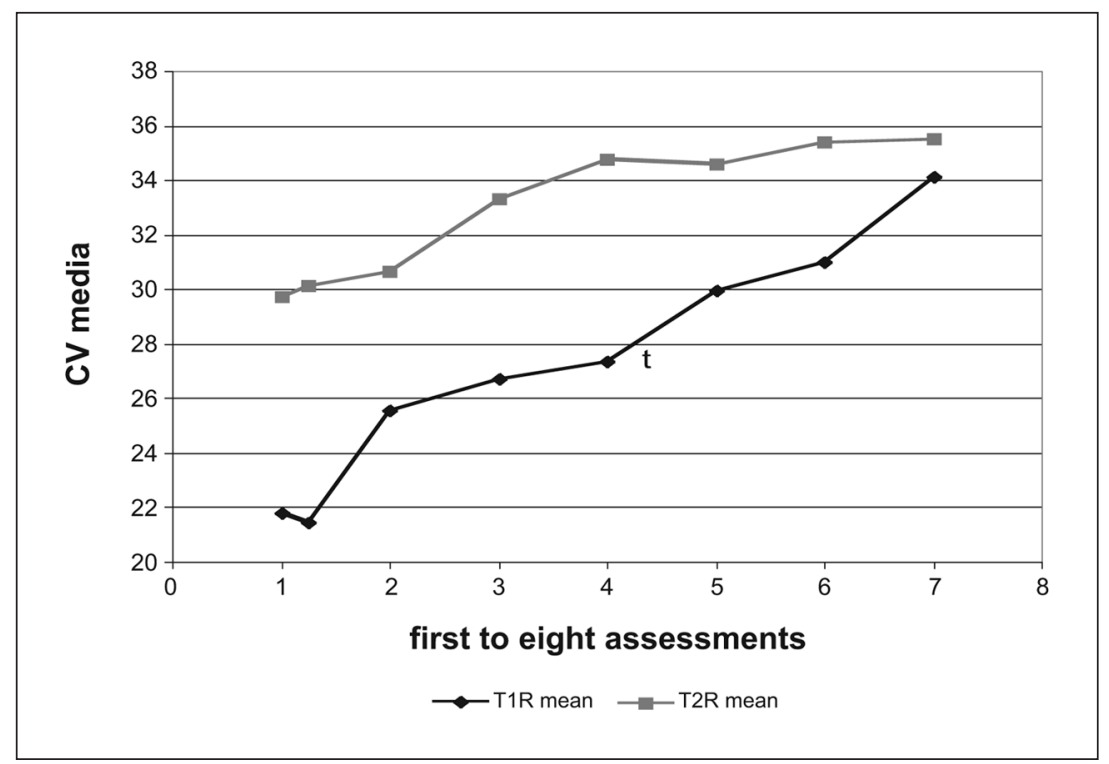

Fig 3. Mean of CV across the elbow during a cohort in nerves of patients of groups $T 1 R$ and $T 2 R(n=28)$. The first CV mean was prior to the treatment and the second was after at the end of the first week, the third at the end of the first month and thereafter monthly until the last occurence at the end of the sixth month

Table 3. The neurophysiological results in nerves with at two different treatment delay periods: less than three months $(<3 \mathrm{~m})$ or more than three months but less than six $(>3<6 \mathrm{~m})$, in patients of $E G$ and CG (TTR and T2R) comparing the $7^{\text {st }}$ evaluation with the $2^{\text {nd }}$, the $7^{\text {st }}$ evaluation with the $3^{\text {rd }}$ and $7^{\text {st }}$ evaluation with the $8^{\text {th }}(n=28)$. The highlighted data are the results with statistical significance and the underlined data are the borderline results.

\begin{tabular}{lccc}
\hline $\begin{array}{l}\text { Treatment delay period } \\
(<3 \mathrm{~m}) \times(>3<6 \mathrm{~m})\end{array}$ & $1^{\text {st }} \times 2^{\text {nd }}$ & $1^{\text {st }} \times 3^{\text {rd }}$ & $1^{\text {st }} \times 8^{\text {th }}$ \\
\hline Distal latency & 0.144 & 0.669 & 0.297 \\
CAMP wrist & 0.621 & 0.766 & 0.558 \\
CV in the forearm & 0.427 & 0.902 & 0.236 \\
CAMP at the elbow & 0.834 & 0.042 & 0.156 \\
CV across elbow & 0.114 & 0.014 & 0.043 \\
CAMP above elbow & 0.191 & 0.041 & 0.256 \\
TD (elbow + above) & 0.097 & 0.069 & 0.225 \\
F wave & 0.157 & 0.037 & 0.014 \\
\hline
\end{tabular}

The results showed a significant improvement of EG in the variables $\mathrm{CV}$ over the forearm and CMAP TD across the elbow during the first week and during the first month. The $\mathrm{F}$ wave latency also showed greater improvement at the end of the first week. In the first week the distal latency showed a slight impairment in the EG group. Improvement was found at the end of first month ( $p=0.082)$. The significant differences disappeared after 6 months.

Statistical differences between the 2 types of reaction were seen only in the improvement of the CV $(p=0.015)$
Table 4. The neurophysiological results in all nerves with symptoms for less than three months $(<3 \mathrm{~m})$ in patients of EG compared with $C G\left(T 7 R\right.$ and T2R) comparing the $7^{\text {st }}$ evaluation with the $2^{\text {nd }}$, the $7^{\text {st }}$ evaluation with the $3^{\text {rd }}$ and $7^{\text {st }}$ evaluation with the $8^{\text {th }}(n=20)$. The highlighted data are the results with statistical significance.

\begin{tabular}{lccc}
\hline $\begin{array}{l}\text { Treatment delay period } \\
(<3 \mathrm{~m}) \mathrm{EG} \times(<3 \mathrm{~m}) \mathrm{CG}\end{array}$ & $1^{\text {st }} \times 2^{\text {nd }}$ & $1^{\text {st }} \times 3^{\text {rd }}$ & $1^{\text {st }} \times 8^{\text {th }}$ \\
\hline Distal latency & $0.046(\mathrm{~T} 1 \mathrm{R})$ & 0.176 & 0.229 \\
CAMP wrist & 0.295 & 0.390 & 0.251 \\
CV in the forearm & $0.046(\mathrm{~T} 1 \mathrm{R})$ & 0.142 & 0.129 \\
CAMP at the elbow & $0.028(\mathrm{~T} 2 \mathrm{R})$ & 0.481 & $0.006(\mathrm{~T} 2 \mathrm{R})$ \\
CV across elbow & 0.196 & $0.081(\mathrm{~T} 1 \mathrm{R})$ & 0.319 \\
CAMP above elbow & $0.041(\mathrm{~T} 2 \mathrm{R})$ & 0.168 & $0.005(\mathrm{~T} 2 \mathrm{R})$ \\
TD (elbow + above) & 0.480 & 0.155 & 0.374 \\
F wave & 0.107 & $0.038(\mathrm{~T} 1 \mathrm{R})$ & $0.053(\mathrm{~T} 1 \mathrm{R})$ \\
\hline
\end{tabular}

and the TD across the elbow $(p=0.033)$ in nerves of patients suffering from $T \backslash R$ compared with patients with $T 2 R$ after 6 months, i.e., at the end of the study. The graphic representation (Fig 3) of the CV in nerves in TIR compared with T2R, before treatment, shows CV markedly lower in $T 1 R$ than in nerves in T2R.

Patients with symptoms lasting less than three months showed significantly greater improvement during the first month in several of the parameters: CMAP at the elbow, $\mathrm{CV}$ across the elbow, CMAP above the elbow, TD across 
the elbow and $F$ wave latency, at the end of first month ( $3^{\text {rd }}$ assessment), when compared with patients whose treatment was delayed (Table 3).

Twenty out of the 28 nerves fell into the category of less than three months treatment delay $(<3 \mathrm{~m})$. When only those 20 nerves were analysed, comparing the EG with the CG, minimal differences were observed. The same parameters improved in EG (CV in the forearm at the first week and $F$ wave latency in the first week and in the last evaluation) and in the CG (CMAP amplitude at the elbow and CMAP amplitude above) in the first week and in the last evaluation. Other parameters, such as wrist CMAP amplitude, VC and TD across elbow did not show statistical differences.

The results show that there is a statistically a greater improvement in patients of the EG than CG, at the beginning of treatment, in the first week, and at the 6th month of evaluation (Table 4).

Two of the patients developed adverse effects of major severity during the trial period, both of them in the EG: one patient developed osteoporosis with collapse of the $10^{\text {th }}$ dorsal vertebra and another developed hyperglycemia and cataracts. Patients of all groups had gained weight at the end of the study.

\section{DISCUSSION}

Several studies have discussed the duration of steroids treatment for reactions and there is evidence that the treatment period for T1R should be longer than the three months recommended by World Health Organization, preferably six or, in some cases, even longer ${ }^{20}$. The duration of treatment for a single episode of T2R is not clear, but there are indications that a reaction usually lasts one month or less ${ }^{21}$. The therapy with higher doses of steroids should be confined to this period in T2R.

Initial steroid dose has infrequently been discussed, although different standard regimens employ different doses. In fact, the initial dose for both reactions and the duration of treatment specifically in neural T2R, has not been fully studied ${ }^{22-24}$.

When the results for the CS were compared, no significant differences were found, either for T1R and T2R (without considering the steroid regimen) or for $E G$ and $C G$ (with T1R and T2R grouped together). Similar results were seen in the literature ${ }^{25}$ when different steroid regimens were compared. Meanwhile, all groups showed significant improvement over time $(p=0.000$ for T1R and 0.046 for $T 2 R$ ), indicating the effectiveness of the chosen treatments (Fig 2). However, Figure 2 shows some differences between the T1R and T2R groups: nerves of T1R patients improve more and continuously while there is a tendency to recur and to abate in T2R patients. In fact, when developing a new reaction, either clinically or in the follow-up parameters, 6 out of the 9 patients in the T2R group needed adjustment of treatment as allowed by the protocol. This usually occurred after one to two months of treatment, when the steroids had reached the doses of 20-30 $\mathrm{mg} /$ day. When increasing the steroid doses and introducing thalidomide improvement was again observed (Fig 2).

In T1R group, relapses of reactions did not occur, contrary to Manandhar's et al. .9 and Sundar Rao et al. ${ }^{26}$ reports, as the treatment period of T1R patients was adjusted to the true duration of 4 to 18 months ${ }^{20}$.

In the comparison of neurophysiologic parameters of the EG and CG, regardless of the type of reaction, statistical differences were found at all three moments evaluated: after the first week $\left(2^{\text {nd }}\right)$, after the first month $\left(3^{\text {rd }}\right)$ and after six months ( $8^{\text {th }}$ assessment) (Table 4). After the first week and at the end of the first month the CV along the forearm and the TD across elbow were significantly better for the EG. These results reflect remyelination. However, the improvement in the first week is most likely a result of reduction of intraneural edema.

These results favor the EG during the first month; this is probably due to the more anti-inflammatory, antiedema effect of the higher steroid doses. After the first month, when the same dose was given to both groups, statistical differences disappeared. However, the improvement of the parameters in the different groups continued. These results indicate a dose-response effect of steroid in the treatment of leprosy neuropathy during reactions, especially at the initial period, when inflammation with edema formation is a major component. The changes in $\mathrm{CV}$ at the elbow demonstrate graphically a remarkable reduction after the second month of the TTR compared to the $T 2 R$, showing more pronounced and continuous remyelination in T1R than in T2R (Fig 3). The repetitive character of the T2R with neural involvement could be a major factor influencing the poor results of long-term treatment of a T2R neuropathy. When the two steroid regimens in T1R were compared, only the TD had significantly greater improvement after 1 month of treatment in nerves of the EG (Table 2). This indicates that an early release of edema may lead to an earlier start of remyelination. In both reactions higher doses show better responses, but in T2R shorter treatment courses may be effective. The use of a higher dose for even an initial short period, as in pulse therapy, should be considered in severe nerve involvement ${ }^{27,28}$.

When only the nerves $(n=20)$ with a delay of less than three months to begin treatment were compared in the EG and CG, the results were similar. These findings corroborate the results from literature ${ }^{2,5}$. Although there were 
slightly better overall EG results in this trial, it is clear that early treatment is more important than the higher dose of steroids.

The frequency of major adverse side-effects of steroids treatment ${ }^{29}$ in the patients of EG was relevant and it must always be taken into consideration.

In conclusion, the responses to steroid showed significance favoring the EG in both T1R and T2R nerves. The effect on nerve showed, at least initially, to be dose-dependent for both the T1R and T2R nerves. Short periods of high doses were effective in $T 2 R$, but additional doses and immunomodulating therapy are required between the reactional episodes. In nerves in which the treatment started early, i.e., less than three months after symptoms began, $1.0 \mathrm{mg} / \mathrm{kg} /$ day (CG) would be as effective as initial doses of $2 \mathrm{mg} / \mathrm{kg} /$ day $(E G)$ for both reactions. Neurophysiologic parameters showed to be more consistent than clinical tests for the outcome assessment in clinical trials.

\section{REFERENCES}

1. Riddley DS, Jopling WH. Classification of leprosy according to immunity: a five group system. Int J Lepr Other Mycobact Dis 1966;34:255-273.

2. Rose P, Waters MFR. Reversal reaction in leprosy and their management. Lepr Rev 1991;62:113-121.

3. Lockwood DNJ, Vinayakumar S, Stanley JNA, McAdam KPWJ, Colston MJ. Clinical features and outcome of reversal (type 1) reactions in Hyderabad, India. Int J Lepr 1993;61:8-15.

4. Wilder-Smith A, Wilder-Smith E. Effect of steroid therapy on parameters of peripheral autonomic dysfunction in leprosy patients with acute neuritis. Int J Lepr 1997;65:20-27.

5. Srinivasan H, Rao KS, Shanmugam N. Steroid therapy in recent "quiet nerve paralysis" in leprosy. Lepr India 1982;54:412-419.

6. Thacker AK, Chandra S, Mukhija RD, Sarkari NB. Electro-physiological evaluation of nerves during reactions in leprosy. J Neurol 1996;243: 530-535.

7. Sugumaran ST. Steroid therapy for paralytic deformities in leprosy. Int. J Lepr 1997;65:337-344.

8. Roche PW, Theuvenet J, LE Master J W, Butlin C R. Contribution of type 1 reaction to sensory and motor function loss in borderline leprosy patients and the efficacy of treatment with prednisone. Int J Lepr 1998;66: 340-347.

9. Manandhar R, Shrestha N, Butlin CR, Roche PW. High levels of inflammatory cytokines are associated with poor clinical response to steroid treatment and recurrent episodes of type 1 reactions in leprosy. Clin Exp Immunol 2002;128:333-338.

10. van Brakel WH, Anderson AM, Withington SG, et al. The prognostic importance of detecting mild sensory impairment in leprosy: a randomized controlled trial (TRIPOD 2). Lepr Rev 2003;74:300-310.
11. Brandsma JW, Van Brakel WH, Anderson AM, Kortendijk AJ, Gurung KG, Sunwar SK. Intertester reliability of manual muscle strength testing in leprosy patients. Lepr Rev 1998:69:257-266.

12. Magora A, Sheshin J, Sagher F, Gonen B. The condition of the peripheral nerve in leprosy under various forms of treatment: conduction velocity studies in long-term follow-up. Int J Lepr 1970;38:149-163.

13. Naafs B, Dagne T. Sensory testing: a sensitive method in the follow-up of nerve involvement. Int J Lepr 1977;45:364-368.

14. Naafs B, van Droogenbroeck JBA. Décompression des névrites réactionnelles dans la lèpre: justification physiopathologique et méthodes objectives pour en apprécier les résultats. Med Trop 1977;37:763-770.

15. Brasil. Ministério da Saúde. Secretaria de Políticas de Saúde. Departamento de Atenção Básica. Guia para o controle da hanseníase. Brasília. (Cadernos de Atenção Básica n. 10, Série A: Normas e Manuais Técnicos, n .111). 2002.

16. Stump RNAG, Baccarelli R, Marciano LHSC, et al. Neuropathic pain in leprosy patients. Int J Lepr 2004;72:134-138.

17. Garbino JA, Opromolla DVA. Monitoração da neuropatia da hanseníase. In Opromolla DVA, Baccarelli R (eds). Prevenção de incapacidades e reabilitação em hanseníase. Bauru: ILSL; 2003:33-36.

18. Lehman LF, Orsini MBP, Nicholl ARJ. The development and adaptation of the Semmes-Weinstein monofilaments in Brazil. J Hand Ther 1993; 6:290-299.

19. Stälberg E, Falck B. Motor nerve conduction study. Method Clin Neurophysiol 1993;4:61-80.

20. Naafs B. Treatment duration of reversal reaction: a reappraisal: back to the past. Lepr Rev 2003;74:328-336.

21. Foss NT, Souza CS, Goulart IMB, Gonçalves HS, Virmond M. Hanseníase: episódios reacionais. In Jatene FB, Cutait R, Cuce Nobre MR, Marques Bernardo W (eds). Projeto diretrizes. São Paulo: Associação Médica Brasileira. Conselho Federal de Medicina; 2003:161-179. Disponível em: http:/ / www.amb.org.br.

22. Lockwood DNJ. Steroids in leprosy Type 1 (reversal) reactions: mechanisms of action and effectiveness. Workshop proceedings: leprosy research at the new millennium. Lepr Rev 2000;71(Suppl):S111-S114.

23. Saunderson $P$. The epidemiology of reactions and nerve damage. Workshop proceedings. Leprosy research at the new millennium. Lepr Rev 2000;71(Suppl):S106-S110.

24. Van Brakel WH. Peripheral neuropathy in leprosy and its consequences. Workshop proceedings: leprosy research at the new millennium. Lepr Rev 2000;71(Suppl):S146-S153.

25. van Brakel WH. Peripheral neuropathy in leprosy: the continuing challenge. Utrecht: Universiteit Utrecht 1994.

26. Sundar Rao PSS, Sugumaran DST, Richard J, Smith WCS. Multi-centre, double blind, randomized trial of three steroid regimens in the treatment of type1 reactions in leprosy. Lepr Rev 2006;77:25-33.

27. Mahajan VK, Sharma NL, Sharma RC, Sharma A. Pulse dexamethason, oral steroids and azathioprine in the management of erythema nodosum. Lepr Rev 2003;74:171-174.

28. Schreuder P A M, Naafs B. Chronic recurrent ENL, steroid dependent: long-term treatment with high dose clofazimine. Lepr Rev 2003;74:386-388.

29. Richardus JH, Withington SG, Anderson AM, et al. Adverse events of standardized regimens of corticosteroids of prophylaxis and treatment of nerve function impairment in leprosy: results from the 'TRIPOD' trials. Lepr Rev 2003;74:319-327. 